Aus dem Angegebenen geht hervor, dass die Hemicellulose I aus 9.2\% Uronsaeure Anhydrid, 73.4\% Arabinose und Xylose (als Anhydroarabinose) und 17.4\% Anhydrogalaktose und die Hemicellulose II aus $15.4 \%$ Uronsaeure Anhydrid, 63.5\% Arabinose und Xylose (als Anhydroarabinose) und 21.1\% Anhydrogalaktose besteht.

\title{
On the Chemical Properties of the Flavon-derivative Contained Tobacco Leaves with Special Referrence to the Colour and Qualities of Cured Leaves.
}

\author{
By \\ Hiroshi Hasegawa \\ (Received August 6, 1931)
}

\section{Summary.}

1) The most important character for grading a cured tobacco leaf is its colour.

2) According to the traditional opinion the colouration of cured tabacco leaves is due to phlobaphene, which is derived from oxydation of tannine by the action of oxydase (O. Loew: Ztbl. Bakt. 2te Abt. VI. 108, 673, 1900).

3) It was now proved that a flavon-derivative is contained always in fresh tobacco leaves and also in nearly all kinds of cured tobacco leaves.

4) The flavon-derivative extracted from fresh tobacco leaves was identified with quercetin-rhamno-glucoside "Rutin $\left(\mathrm{C}_{27} \mathrm{H}_{32} \mathrm{O}_{16} \cdot 2 \mathrm{H}_{2} \mathrm{O}\right)$ " on the ground of several physical and chemical properties.

5) The colour-change of the ordinary Japanese tobacco during its curing process may be divided practically into four stages, i. e.

1st : the drying leaves yet show a "greenish colour",

2nd: the leaves turn "yellowish" (yellowing stage),

3rd: the leaves become almost "brownish" (brownish stage),

4 th: the leaves show a "nearly unchangeable brown colour" (fixed colour stage).

Microscopical observations upon the development and distribution of colouring matter in the leaf-cells from these four stages gave following results.

In the 1 st stage the epidermal cells are colourless, but the palisade and inner parenchymatous cells are filled with chloroplasts. In the 2 nd stage epidermal cells appear yet colourless, but the palisade and inner parenchymatous cells are losing their green colour and turning yellow, owing to the 
carotinoid pigments, which remained after the decomposition of chlorophyll. Throughout the 3rd and 4th stages the inner tissues do not change their yellowish colour, while the reddish-brown colouring matter is found accumulating in the epidermal and adjacent cells though the mode of colour distribution can not be made out exactly in broken and collapsing tissue cells.

6) Cobaltpentamminchloride solution, which is known to easily oxidise Rutin, was allowed to act upon the fresh tobacco leaves inducing thereby the so-called "vitaloxydation". It was then observed that the colour of epidermal cells were changed yellow, red and brawnish successively, and the palisade and inner parenchymatous cells were at first greenish in colour, but gradually turned yellow. These colour changes, progressing slowly both in epidermis and inner cells, show much resemblances with those observed during the curing process. Moreover the above mentioned results indicated that the colouring matter is mostly localised in the epidermal cells. For detailed examination the epidermis stripped off from underlying tissue was immersed in a $1 / 100 \mathrm{~mol}$. solution of cobalt-pentamminchloride and the gradual development of oxidation coloures, yellow to brown, was clearly observed under the microscope.

7) The above mentioned colour changes occuring in epidermal cells of tobacco $(\mathrm{N}$. Tabacum, N. glauca) corresponds exactly to the oxdative reaction of Rutin caused by cobalt-pentamminchloride in test tube experiments. The epidermis of tobacco leaves become deep green upon the treatment with ferric chloride, the reaction also showing the presence of Rutin. On the other hand the leaf-epidermis of Pelargonium Zonale gives a blue reaction due to tannine. Thus it might be well concluded that the colouration of cured tobacco leaves is caused essentially by the oxidation product of Rutin contained in epidermal cells.

8) Quantitave determinations of the flavon-derivative in 233 kinds of the cured leaves by means of colorimetric and titration methods have shown in general that this substance is contained more abundantly in bright-coloured better leaves than in discoloured inferior ones, and also richly more in newer than in older leaves.

9) On the other hand any relation between tobacco tannine and the colour of cured leaves was not clearly indicated by means of ferric chloride and soda, except in the parts of vasculer bundles. 